Otterbein University

Digital Commons @ Otterbein

2011

\title{
Object-based Epistemology at a Creationist Museum
}

\author{
Paul J. Wendel \\ Otterbein University
}

Follow this and additional works at: https://digitalcommons.otterbein.edu/edu_fac

Part of the Education Commons

\section{Repository Citation}

Wendel, Paul J., "Object-based Epistemology at a Creationist Museum" (2011). Education Faculty Scholarship \& Creative Works. 2.

https://digitalcommons.otterbein.edu/edu_fac/2

This Article is brought to you for free and open access by the Education at Digital Commons @ Otterbein. It has been accepted for inclusion in Education Faculty Scholarship \& Creative Works by an authorized administrator of Digital Commons @ Otterbein. For more information, please contact digitalcommons07@otterbein.edu. 


\title{
Object-Based Epistemology at a Creationist Museum
}

\begin{abstract}
In a regional young-earth creationist museum, objects are presented as if they speak for themselves, purportedly embodying proof that the earth is less than ten thousand years old, that humans have lived on earth throughout its history, and that dinosaurs and humans lived simultaneously. In public lectures, tours, and displays, museum associates emphasize direct observation over inference or theory. These emphases resonate closely with the "object-based epistemology" of the late $19^{\text {th }}$ century described in Steven Conn's Museums and American Intellectual Life, 1876-1926. In Conn's description, museum objects, artfully arranged and displayed, were intended to speak for themselves, and observation and categorization were valued over experiment and theory. The regional young-earth creationist museum is observed to partly succeed and partly fail in implementing an object-based epistemology. Although object-based epistemology represents a $19^{\text {th }}$-century approach to knowledge and museum display, it is compatible with an inductive approach to biblical interpretation and it confers various rhetorical advantages to creationist arguments. It is concluded that a focus on the theory-laden nature of data would likely strengthen nature-of-science education efforts to increase public acceptance of evolution.
\end{abstract}

\section{Introduction}

Although "scientific creationism" is a late $20^{\text {th }}$ - and early $21^{\text {st }}$-century phenomenon, an investigation of the Fossil Museum (pseudonym), a small creationist facility in the Midwestern U.S., reveals a $19^{\text {th }}$-century epistemology. Here museum associates emphasize that data should speak for itself without the contaminating influence of theories or other preconceived notions. This view of data is consistent with the inductive approach to biblical interpretation characteristic of conservative Christianity, in which the believer is encouraged to read the Bible in a plain-sense, literal way with few or no preconceptions. Since all of the Fossil Museum staff and most of the visitors are conservative Christians, this highly inductive approach to data should appeal to staff and visitors alike. The notion that data should be interpreted in a theory-free way also confers the rhetorical benefit of elevating creationists from a status of scientific outsiders to the status of rival interpreters of data.

Yet for all of its appeal, $20^{\text {th }}$-century scholars have soundly rejected the notion of theory-free data. The inherent difficulties of attempting to maintain a theory-free approach to data arise in the Fossil Museum's main exhibit hall. Here the displays are presented as a theory-free collection of objects and arguments, untainted by theoretical commitments. However, the museum staff does not leave the objects to speak for themselves. With few exceptions, each guest's first visit to the main exhibit hall includes a mandatory guided tour characterized by extensive explanations of the objects on display and their (negative) implications for mainstream science. The objects on display are accompanied by often extensive written explanations. Thus we find a tension between efforts to allow objects speak for themselves without contaminating theories and efforts to use objects as the foundation for (often complex) arguments. Nonetheless, museum associates do not acknowledge the theoretical lenses through which they view the objects on display, so this tension remains unrecognized. 
Science educators agree that understanding the nature of science contributes to acceptance of the theory of evolution. However, the nature of science includes many elements, and accordingly nature-of-science education efforts tend to be broad. The importance of the notion of theory-free data at the Fossil Museum suggests that natureof-science education efforts could profitably focus on the theory-laden nature of data. Focus on such a counterintuitive and potentially confusing idea, however, will be difficult.

\section{Object-Based Epistemology}

In Museums and American Intellectual Life, 1876-1926, Steven Conn (1998) describes an "object-based epistemology" of the late nineteenth century. In Conn's narrative, nineteenth-century museum curators believed that if they carefully arranged and displayed objects, the objects would serve as metonyms for larger bodies of knowledge and therefore reveal knowledge about the world. The objects would speak for themselves in a language accessible to anyone, both amateur and specialist, who took the time to study them.

Yet in Conn's account, object-based epistemology did not last long, as it was gradually abandoned in favor of theoretical and experimental approaches to scientific discovery over the last quarter of the nineteenth century and the first quarter of the twentieth century. Conn illustrates the abandonment of an object-based epistemology in biology's gradual migration away from "naked-eye science" with the rise of Darwinism:

[T]he natural history museums built after the Civil War maintained pre-Darwinian principles of natural science even as those principles were challenged fundamentally. Darwinian natural history might at first fit comfortably into natural history museums. His theory of natural selection helped explain the Great Chain of Being these museums put on display. Ultimately, however, Darwinian theory shook the foundations of these museums and the kind of natural history they fostered. The theory drew natural history into new areas of research, away from morphology and toward genetics, from whole organism biology into cellular biology, from science that could be conducted with the naked eye toward science that needed a microscope (Conn 1998).

Under the influence of Darwin's new theoretical emphasis, the biological sciences were in large part moved out of the public domain, and instead biology became highly specialized, professionalized, and less accessible to the general public. The same was true in other sciences such as physics, where relativity and quantum physics effectively moved the most important research beyond the visible or the intuitive. As Conn describes it,

The new science ... was driven by contentious and abstract theory, not simply by observable facts. Theories needed facts to prove or disprove them, but those facts were ultimately less interesting than the theories themselves. But unlike the "facts" of the old natural history, these new theories were precisely disputable, and in the most troubling ways. Indeed, the whole endeavor of the new science was predicated on conflict and debate (p. 66). 
The clarity implied in a highly observable object-based epistemology was displaced by the opacity of theory-based reasoning. Furthermore, Conn argues that this shift from an object-based epistemology to experiment- and theory-based inquiry contributed to the marginalization of museums as sites of knowledge production. In particular, museums' continued emphasis on objects and the "facts" embodied in their collections inexorably pushed the intellectual focus of knowledge production into universities.

\section{Young-Earth Creationism}

Present-day young-earth creationists interpret the book of Genesis as a factual account of earth history, and they claim to have found physical evidence supporting their beliefs. In particular, they claim to have found physical evidence indicating that the earth was created in six 24-hour periods less than ten thousand years ago, that most of the geologic column was laid down in a year-long worldwide flood, and that life was created suddenly and (approximately) in its present form (e. g., see the seminal text by Whitcomb and Morris 1961). By contrast, present scientific theory holds that the earth is approximately 4.5 billion years old, that most of the geologic column was gradually deposited over this time by natural geologic processes, and that life developed on earth through a process of evolution. Consequently young-earth creationists attempt to controvert mainstream science by introducing unconventional physical evidence, disputing the interpretation of accepted physical evidence, and as we shall see, disputing the nature of scientific inquiry.

\section{Method}

The motivating question at the outset of this investigation was: How do creationists separate science from non-science? That is, by what criteria do they admit some information (most of modern chemistry, medicine, meteorology, etc.) as valid and "scientific" while rejecting other information (such as radiometric dating, cosmology, the theory of evolution, etc.)? Do creationists simply reject anything that contradicts their reading of the Bible, or do they apply more subtle and varied criteria? As the study proceeded, the Fossil Museum's highly inductive approach to science began to emerge as a recurrent theme. After completing the field work, I encountered Conn's notion of an object-based epistemology and began to examine the close resonance between this epistemology and Fossil Museum practice. The present paper is the fruit of this progression.

In order to explore how creationists separate science from non-science, I conducted a nearly two-year case study (Flyvbjerg 2001, 2004; Stake 2003) of the Fossil Museum, a regional young-earth creationist facility which opened near a Midwestern city in 2005. Of the 100+ regional creationist institutions in the U. S. (Creation Research Society 2008), I selected the Fossil Museum for study because of its convenient location, its variety of programs, its relatively long hours of operation (open six days per week in the summer and three days per week during the school year), and its explicit competition with mainstream science. I photographed all exhibits, analyzed them for sourcing and content in both creationist and non-creationist literature, and examined them for common themes (Hodder 2003). I accompanied guided tours, attended special programs for adults 
and children, and observed staff and visitors at the museum. I attended, recorded, transcribed, and coded eighteen Fossil Museum public lectures (Silverman 2003). I recorded, transcribed, and coded semi-structured interviews with 35 visitors (Fontana and Frey 2003; Briggs 1986). Names and minor details were altered to protect the identities of Fossil Museum visitors, speakers, and employees.

As an agnostic holding mainstream scientific views (evolution of life on earth, antiquity of the earth and universe, etc.), gaining permission to study the museum was difficult. Following several informal visits to the museum, I formally requested permission to conduct a source-protected study. About six weeks later, I was invited to present my proposal to the Fossil Museum's Board of Trustees. At this meeting I emphasized my desire to be fair and accurate, and in response to the question, "What do we [the Fossil Museum] gain from your study", I replied that the Board would get a sense for how an outsider (one who does not share the Board's religious or scientific commitments) views the museum. Several weeks later the Board granted permission to conduct the case study, partly because they were convinced of my intention to be fair and partly, I suspect, because of their hope that the Fossil Museum's evidence might win me over. I conducted the study under the supervision of my home institution's Institutional Review Board.

\section{The Fossil Museum}

The Fossil Museum's founder, pseudonym Art, is a businessman in his mid-fifties. For about twenty years before opening the museum, Art had been collecting fossils and creationist artifacts and conducting creationism seminars in local churches. Eventually he gathered a board of trustees and together they formed a non-profit corporation to open and operate the Fossil Museum. They acquired a 5,000-square-foot building on several acres of land in a semi-rural area of the Midwestern United States. Within the Fossil Museum, staff and exhibits present astrophysical, geological, historical, and biological arguments that the universe is less than 10,000 years old and that complex organisms could not have evolved from simpler forms. Outdoors is Fossil Park (pseudonym), a multi-acre playground equipped with standard playground equipment plus spectacular extras such as an eight-foot-tall model of a Sauropod, a dinosaur-themed water-balloon launching game, and a 200-foot zip-line ride. Art oversees the Fossil Museum and Park, but he is not a paid employee. The paid staff includes a full-time director and about ten part-time and/or seasonal employees. The staff conducts hourly museum tours, hosts birthday parties, runs a gift shop, operates the zip-line ride, offers games in Fossil Park, and maintains a web site. The paid staff also hosts monthly science classes for elementary and middle-school students and several week-long summer day camps. For adults, the museum hosts a monthly lecture series presented by museum staff, local speakers, or creationists from other states.

\section{Object-Based Epistemology at the Fossil Museum: Theory-Free Data}

An object-based epistemology depends on the notion that properly displayed objects can "speak for themselves" without the intervention of or need for complex theories to make 
the information accessible. That is to say, object-based epistemology depends on the existence of theory-free data. Yet during the latter half of the $20^{\text {th }}$ century, philosophers and historians of science reached a near-consensus that data cannot be theory-free. For example, Norwood Russell Hanson $(1958,1969)$, an early and sharp critic of the notion of theory-free data, wrote that observation and data are inextricably "theory-loaded", and as a result facts can never speak for themselves:

Thus [William] Harvey's circulation hypothesis [that the heart circulates blood throughout the body] and Galileo's constant-acceleration hypothesis make sense only against the considerable background of their respective collections of stable knowledge. To one who lacked the background of either of these great investigators, letting the facts about blood motion or falling-body motion merely speak for themselves would have issued in an unearthly silence (Hanson 1969).

Hanson's successors (e. g., Kuhn 1970; Lakatos 1972; Feyerabend 1975; Churchland 1979) developed the notion of theory-ladenness of data, and as the notion became accepted, discussion focused on the degree and implications of the thesis (e. g., Fodor 1984; Brewer and Lambert 2001). To Thomas Kuhn, for example, the differences between the Aristotelian and Galilean worldviews amounted to more than rival interpretations of the same data. Instead, the data itself was different, as in the case of a pendulum:

To the Aristotelians, who believed that a heavy body is moved by its own nature from a higher position to a state of natural rest at a lower one, the swinging body was simply falling with difficulty. Constrained by the chain, it could achieve rest at its low point only after a tortuous motion and a considerable time. Galileo, on the other hand, looking at the swinging body, saw a pendulum, a body that almost succeeding in repeating the same motion over and over again ad infinitum (Kuhn 1970).

Kuhn famously concluded:

Until that ... paradigm was invented, there were no pendulums, but only swinging stones, for the scientist to see. Pendulums were brought into existence by something very like a paradigm-induced gestalt switch (p. 120).

Kuhn argued that theory brought a new kind of data (the near-repeated motion of a pendulum) into existence. Although not all historians and philosophers agree with Kuhn, they have come to agree that theory is indispensable to the collection, organization, and interpretation of data, that is, that theory and data are mutually dependent, working handin-hand in the development of human knowledge. Therefore from a scholarly perspective, an object-based epistemology has become untenable in science.

In public lectures, speakers explicitly advocate an object-based epistemology as they advance the notion that data can be/should be theory-free, and that "assumptions" contaminate the proper interpretation of data. For example, in a public lecture, the Fossil Museum founder, pseudonym Art, expressed the notion of theory-free data as follows: 
“... keeping in mind the evidence doesn't change. We've oftentimes said the evidence doesn't change. It is always our assumptions about the evidence that are in question.

This is a shell, OK? Is it old or is it young? That's always the interpretation. The evidence doesn't change. As we've oftentimes said in the museum, the facts are cast in stone. What's not cast in stone is our interpretation of the evidence".

In Art's view, geologic data is stable, "cast in stone", while interpretation of that data is unstable, driven by human assumptions or theories. Where present-day philosophers or historians describe theory and data as mutually determinative, Art describes data as standing independent of theory. As in an object-based epistemology, theory is superfluous to data.

At the Fossil Museum, assumptions are not viewed as elements of an explanatory framework which are indispensable to scientific study, but rather as contaminants to data. A frequently cited example of such contamination is in the history of the geologic column. In the Fossil Museum version of this history, the geologic column was developed as an organizational principle for data about rock layers and was compatible with the creationist belief that most of these layers were deposited during the Noachian Flood. However, in Fossil Museum rhetoric the geologic column was co-opted and distorted by old earth/evolutionary geologists. That is, a theory was imposed on the data. For example, on one occasion Art interrupted a lecture by the Fossil Museum director (pseudonym Ben) to recount the story:

Art: Well the other thing too, Ben, that, and we talked about this, is the geologic time scale. It was actually invented originally by two creation scientists, and their names escape me, although I do have the information. With the whole idea of trying to organize identifying layers of rock. It was only later that the geological time scale...

Ben: Right.

Art: $\quad \ldots$ was added to the geologic column ...

Ben: Right.

Art: $\quad$. . by the evolutionary thinking process. So, you know, when you look at those kinds of things, the assumption of evolution and things changing over time was imposed upon the original thought of a geologic column defining rock layers.

Ben: Right.

In this description, creationists invented the geologic column in order to "organize identifying layers of rock", but "the assumption of evolution and things changing over time was imposed upon the original thought". ${ }^{1}$ Part of the Fossil Museum's mission is to

\footnotetext{
${ }^{1}$ Many thinkers contributed to the development of the geological column through the hundredyear period before the 1859 publication of the Origin of Species (Wyse Jackson 2006), but few quantitative age estimates appeared before the first edition of the Origin (see Darwin 1859/2009)
} 
point out and reverse such impositions/assumptions so that the data can be restored to its pure form.

An object-based epistemology trusts the observable over the unobservable/theoretical. A visiting lecturer who holds a $\mathrm{PhD}$ in a natural science (pseudonym Dr. Nichols) recruited this preference for observation over inference in an effort to challenge the idea that dogs and cats share a common ancestor:

“And then the DNA evidence would support wolves as being the common ancestor [to all dogs]. So it's a descent with modification but within limits is what I would say about that. So that's what we observe experimentally. We observe dogs making dogs, wolves radiating out to other types of similar kinds of animals. But we don't see the, a common ancestor in the sense of millions of years of evolution turning into a dog or turning into a cat. There's the rapcid ${ }^{2}$ which is like the common ancestor between dogs and cats. They both came from the same thing according to the macroevolutionary view. We don't see that. We see dogs making dogs and cats making cats. And say, well it takes too long. Well then, that's not experimentally observable, so then it's presumption or inference. So you're dealing with interpretation of the data. It's a historical, nonreproducible vs. reproducible".

Here Dr. Nichols reasoned that the development of new dog varieties is defensible because it can be directly observed, while the development of dogs and cats from a common ancestor is not defensible because it cannot be directly observed - it is "presumption or inference". Consistent with an object-based epistemology, Dr. Nichols restricts good science to the directly observable, while demoting "inference" to presumption or even to flights of fancy.

\section{Object-Based Epistemology at the Fossil Museum: Displays}

In present-day museums, ideas are more important than the objects used to illustrate those ideas (Weil 1990a). Where objects were left to speak for themselves in the $19^{\text {th }}$ century, under-documentation of objects is presently recognized as a serious error (Miles et al. 1988). Object authenticity was once paramount, but now imitations or objects of questionable provenance may be displayed to illustrate a concept (Weil 1990b; Crew and Sims 1991). In early museums, objects were thought to carry their own meaning, but present-day curators recognize that removal of an object from its everyday context (Alpers 1991; Annis 1994) or a change in method of museum display (Vogel 1991) alters the meaning assigned to an object. In an object-based epistemology, museum display begins with objects and then the objects induce conclusions. In modern museums, particularly those housing large collections, designers begin with ideas and then carefully craft displays and choose objects to illustrate those ideas.

and many multi-million-year age estimates appeared over the following 50 years (Wyse Jackson 2006). Availability of geologic data was likely a key factor.

${ }^{2}$ Dr. Nichols probably meant the miacids, thought to be ancestors to all carnivorous mammals. 
Consistent with the primacy of ideas over objects, mainstream natural history museums are typically laid out in a strong narrative structure of themes and subthemes (Miles et al. 1988). At the American Museum of Natural History in New York, for example, fossils are placed by overall evolutionary relationship, allowing the visitor to walk along particular trunks and branches of an overall evolutionary tree (Dingus et al. 1994; Asma 2001; Maisey et al. 1996). In this case evolutionary theory provides a story line while the objects on display provide points of focus for the story line. The objects aren't the story, but contributors to the larger narrative.

In its two exhibit halls, the Fossil Museum demonstrates contrasting philosophies of museum display. The "Creation Walk" exhibit hall resembles modern museum design in its strong narrative structure. In this hall, footprints painted on the floor guide visitors through the seven-day creation week, the story of Adam and Eve's sin in the Garden of Eden, and the Noachian Flood based on the first eight chapters of Genesis. Along the way, the visitor encounters Bible passages followed by young-earth creationist interpretations of each passage. For example, excerpts from the story of Adam and Eve's sin and resulting punishment (Genesis 3 ) are accompanied by text postulating that Adam's sin brought the second law of thermodynamics into existence (the increase in entropy of a closed system). The Creation Walk displays large amounts of text and very few objects. Here the story is primary.

The "scientific" exhibits are housed in the main exhibit hall. Unlike the Creation Walk, there is little story in the main exhibit hall-here the objects are primary. Displays are not coordinated to illustrate a specific creationist narrative, but presented as a series of disconnected disproofs to mainstream science. For example, a display of "out-of-place artifacts" (such as castings of an iron cup purportedly found embedded in coal and a hammer supposedly found in 140-million-year old stone according to conventional dating) discredit the notion that humans arrived relatively recently in geologic history. An adjacent display attempts to discredit radiocarbon dating. Here a small poster features a drawing of a mammoth and text alleging that conflicting radiocarbon dates were produced from different parts of the same mammoth specimen. Beside this display, a graph of human population growth demonstrates (according to the tour guide) that there are too few people on earth for humans to have existed for more than 6,000 years. Other displays argue that the Sahara Desert is growing too fast to support a 4.5-billion-year-old earth, that the continents would "erode flat" in only 14 million years, that the earth's magnetic field intensity is declining at such a rate that the earth could not be older than 25,000 years, that the distribution of galaxies across the universe is too uneven for a Big Bang to have occurred, and many more. Each argument is independent of its neighbor, and any one of them could serve as the "smoking gun" to discredit mainstream science. All of these arguments are spurious (see Author 2008), but they are also highly accessible, with the text and tour guide providing all of the explanation and background knowledge necessary for the visitor to confidently conclude that thousands of mainstream scientists must have earth history wrong. Although the "objects" generally take the form of castings, photographs, drawings, or graphs, we have an object-based epistemology in the sense that the data is intended to speak directly to the visitor without guidance of a larger narrative or the intervention of complicated theories. 
Yet the main exhibit hall also reveals the contradictions inherent to an objectbased epistemology. First, consistent with standard museum practice (Miles et al. 1988; Dean 1994), the Fossil Museum extensively labels many of the objects on display, and in some displays the Fossil Museum exceeds recommendations for length and detail (Hjorth et al. 1977; Dean 1994; Spencer 2002). For example, several exhibits attempt to demonstrate that humans and dinosaurs lived at the same time. ${ }^{3}$ One of these is a series of photographs of allegedly 2,000-year old clay figurines supposedly excavated near Acambaro, Mexico in the 1940s and 1950s. The display includes over 1,200 words of text, raising the question of why so much information must accompany "theory-free" data.

As the Fossil Museum attempts to present theory-free data, a second inconsistency can be observed in the Museum's touring policy. The National Research Council characterizes museums as "navigated freely, with limited or often no direct facilitation from institutional actors. Visitors may freely choose which of the exhibits to interact with, and they receive little guidance as to which path they should follow as they explore" (Bell et al. 2009; see also Gurian 1991). By contrast, a first-time visit to the Fossil Museum always begins with a 15-minute classroom presentation and a 20-25 minute guided tour of museum displays. Visitors are granted free access to museum displays only after this initiation. The Fossil Museum founder (Art) and director (Ben) confirmed that this is institutional policy, and I observed exceptions to this policy only for visiting speakers or other creationist experts. Although Art or Ben might defend this initiation policy as a matter of helping visitors to interpret data without contaminating assumptions, such a policy indicates that the objects on display do not, in fact, speak for themselves, or at least not in an unequivocally creationist register.

The first stop on the tour of the main exhibit hall illustrates the importance of the tour guide. Here a display of "burial stones" provides dramatic (if spurious) evidence that dinosaurs and humans coexisted. Visitors can handle five castings of smooth 6-inch river stones with images carved on them, said to have been retrieved from ancient tombs near Ica, Peru (for creationist accounts, see Patton 2000; Swift 2006). All of the carvings depict images of dinosaur-like creatures, and four of the five include images of people. Yet the images are strange and cartoonish, so tour guides typically spend about 3-4 minutes (longer than any other display) describing the history of discovery and authentication of the objects, describing the history of the Ica people, interpreting the odd scenes depicted on the stones, and pointing out details on the drawings indicating that they depict dinosaurs rather than modern-day lizards. In short, the stones require extensive explication and theory to transform them into creationist evidence.

Despite the rhetoric of theory-free data, we see that the Fossil Museum is unable to present data without theory. On one hand the main exhibit hall is characterized by a

\footnotetext{
${ }^{3}$ This astonishing claim is common among young-earth creationists (Whitcomb and Morris 1961; Morris 1980; e. g., Ham 2008). Fossil Museum arguments to this effect are critiqued in Author 2008.
} 
lack of narrative structure, presented as a group of disconnected disproofs of mainstream science. On the other hand the displays are characterized by extensive labeling and a mandatory guided tour. The result is a $19^{\text {th }}$-century object-based epistemology compromised by $20^{\text {th }}$-century museum conventions.

\section{Object-Based Epistemology and Biblical Literalism}

In his study of the $19^{\text {th }}$-century educator Alfred Holbrook, Nathan Myers (2007) noted a close association between Holbrook's object-based pedagogy and the Judeo-Christian tradition. There is good reason for this close association. A cornerstone of the Protestant reformation was the abandonment of allegorical readings of scripture in favor of more straightforward interpretations (Harrison 2006). In American fundamentalism, this style of biblical interpretation hardened into a highly inductive form of biblical literalism: without preconceived ideas, one reads the "facts" of scripture and collects them into principles and conclusions. Under the influence of Scottish Common Sense philosopher Thomas Reid, this inductive approach to scriptural interpretation found its parallel in an inductive approach to science among American fundamentalists (Taylor 1996; Marsden 1991, 1980, 1984; Bozeman 1977). Informed by this heritage, American creationists approach knowledge in a strikingly inductive way (Taylor 1992, 1996).

Given this history, it is not surprising that at the Fossil Museum we find evidence of mutual support between biblical literalism and a highly inductive/object-based epistemology. In a particularly striking example, the audience rewarded a visiting speaker with "Amens" and other words of encouragement when he said: "I only have one basic passion in my life. If it hadn't shown through yet, I believe that the Bible is true from the first verse to the last, and it's interpreted by itself in context" (emphasis added). Here self-interpretation of scripture articulates perfectly with the self-interpretation of the natural world advocated by the Fossil Museum, an object-based epistemology displaced to scriptural interpretation.

\section{Rhetorical Advantages of an Object-Based Epistemology}

Although poorly supported in historical and philosophical scholarship, the notions of assumption-free data and a sharp distinction between observation and inference confer several rhetorical benefits to the Fossil Museum. First, the ideal of assumption-free data supports the Fossil Museum claim that fair-minded examination of the evidence would lead to the young-earth creationist point of view. Therefore if mainstream scientists would only set aside their evolutionary and old-earth assumptions and follow the data, they would arrive at the young-earth position independently of any religious commitments. Experience has taught that such scientist conversions are unlikely, so the main value of the claim may lie in its utility for comforting biblical literalist visitors that their faith is confirmed in physical evidence. On the other hand, the rhetoric of theoryfree data may help to disarm skeptical visitors, persuading them to recognize their assumptions and to suspend judgment until observing the evidence first-hand. 
The notion of assumption-free data also helps to de-marginalize creationists. Scientists typically view creationists as outsiders attempting to invade and corrupt legitimate science. But in laying claim to the "same data" that scientists have, Fossil Museum associates attempt to elevate themselves from the outsider status of marginalized pseudoscientists to the insider status of rival interpreters. Here creationist assumptions become neither more nor less reasonable than scientists' assumptions - after all, both are "assumed" rather than "derived" or "proven". Since only the (theory-free) "facts" are "set in stone" - the rest is a matter of assumption - then creationists can argue that their religious commitments should not deny them a seat at scientific discussions.

The theory-laden nature of observation invalidates a sharp distinction between inference and observation, but Dr. Nichols' emphasis on observation and tendency to discount inference may be attractive to museum visitors simply because vision is the dominant sense in humans. Because of a preference for the visual, lay consumers of scientific knowledge tend to privilege images over other kinds of information (see, e. g., Weinstein 1998). Brain scans, for example, evoke a sense of certainty among the general public that far exceeds the confidence of the scientists who produce them despite the scientists' cautions and disclaimers (Dumit 2004). To the extent that seeing is believing, observation trumps inference, which in turn favors an object-based epistemology.

\section{Conclusion: Emphasizing the Mutual Dependence of Theory and Data}

Many scientists and science educators argue that teaching the nature of science (NOS) is key to reducing resistance to evolutionary instruction (National Academy of Sciences 1998; National Association of Biology Teachers 2001; National Science Teachers Association 2003; Olson 2004; Attie et al. 2006; Barclay 2006; Clough 1994; Farber 2003; Flammer 2006; Narguizian 2004; Nickels, Nelson, and Beard 1996; Scharmann and Harris 1992). Despite this broad agreement, few studies have tested the hypothesis that understanding of the nature of science correlates to acceptance of the theory of evolution as a valid and useful explanatory tool. In an early study, Johnson \& Peeples (1987) found a positive correlation between postsecondary biology students' NOS understanding and acceptance of evolution $(r=0.45)$. Since then, follow-on evidence has been thin. Workers have found that instructional interventions improve both the acceptance of evolution and the understanding of NOS among high school students (Scharmann 1990), secondary biology \& earth science teachers (Scharmann and Harris 1992), and preservice science teachers (Scharmann et al. 2005), but none of these studies tested for a correlation between the improved NOS understanding and acceptance of evolution. In a study of high school biology teachers, Rutledge \& Warden (2000) measured the strongest correlation so far between NOS understanding and acceptance of evolution $(\mathrm{r}=0.76)$. However, the measurement of "acceptance of evolution" in the Rutledge \& Warden study relied on an instrument (Rutledge and Warden 1999) which may conflate understanding of evolution with acceptance of evolution (Smith 2010). Furthermore, none of these studies attempted to establish a causal relationship between understanding of the NOS and acceptance of evolution. 
In the present study, we saw that the Fossil Museum's object-based epistemology disregards the notion that data is or should be theory-laden. This supports the consensus view that misrepresentation of the nature of science is an important factor in religiouslymotivated antievolutionary rhetoric, and it also suggests that NOS education could more effectively counterbalance antievolutionary sentiment by focusing on the theoryladenness of data. Yet such a focus presents a challenge for a variety of reasons. First, the notion of theory-free data is not easily dislodged from science education. For example, the notion of theory-free data has historically been found in science textbooks (Jacoby and Spargo 1989; Matthews 1994), and many science teachers appear to maintain a naïve inductivist/empiricist view of science (see the literature reviews in Hipkins 2005; McComas, Clough, and Almazroa 1998). In a longitudinal study of a single teacher, the notion of theory-free data proved to be particularly slow to change (Da-Silva et al. 2007). Second, the theory-ladenness of data is one of 14 identified NOS objectives found in a "consensus view" of international science standards documents (McComas, Clough, and Almazroa 1998). As a result, theory-ladenness can easily be lost among the other 13 NOS objectives.

A third difficulty is that the theory-ladenness of data is a difficult, counterintuitive, and easily misunderstood concept. Beginners could easily get the impression that the theory-ladenness of data implies that science is disconnected from reality, or that theory-ladenness confers equal standing to all claims, or that theory-laden data is tainted while theory-free data is reliable. Hints of the latter misunderstanding appear in creationist literature, where the rarely-used term "theory-laden" takes on a cautionary tone. For example, an author advises a fellow creationist:

I especially want to emphasize in this submission that we need to examine all of the data thoroughly, since it usually comes from uniformitarian sources and may be either theory laden or not a complete data set (Oard 2002, emphasis original).

Perhaps the author recognizes that all data is theory-laden, but if so, the statement does not carry much weight as a caution (for similar uses of "theory-laden" see Oard 2000; Mortenson 2010). A closely related fourth difficulty is that some educators may worry that even when fully understood, the notion of theory-laden data could become part of creationist rhetoric in the same way that postmodern/“deconstructionist" language has found its way into creationist arguments (Pennock 1999). This may occur, but the present study suggests that theory-free data is an important part of the creationist view of science. Consequently an accurate understanding of the theory-ladenness of data is a necessary, if not sufficient, condition for acceptance of the validity and utility of evolutionary theory. 


\section{References}

Alpers, S.: 1991, "The Museum as a Way of Seeing". In I. Karp \& S. D. Lavine (eds) Exhibiting Cultures: The Poetics and Politics of Museum Display, Smithsonian Institution Press, Washington, DC, pp. 25-32.

Annis, S.: 1994, "The Museum as a Staging Ground for Symbolic Action". In G. Kavanagh (ed.) Museum Provision and Professionalism, Routledge, London, pp. 21-25.

Asma, S. T.: 2001, Stuffed Animals \& Pickled Heads: The Culture and Evolution of Natural History Museums, Oxford University Press, New York.

Attie, A. D., Sober, E., Numbers, R. L., Amasino, R. M., Cox, B., Berceau, T., Powell, T., \& Cox, M. M: 2006, "Defending Science Education against Intelligent Design: A Call to Action", Journal of Clinical Investigation 116, 1134-1138.

Barclay, G.: 2006, "The Importance of Teaching the Nature of Science: Helping Our Students Battle Pseudoscientific Ideas", The American Biology Teacher 68, 261262.

Bell, P., Lewenstein, B., Shouse, A. W., \& Feder, M. A. (eds.): 2009, Learning Science in Informal Environments: People, Places, and Pursuits, National Academies Press, Washington, DC.

Bozeman, T. D.: 1977, Protestants in an Age of Science: The Baconian Ideal and Antebellum American Religious Thought, University of North Carolina Press, Chapel Hill.

Brewer, W. F., \& Lambert, B. L.: 2001, "The Theory-Ladenness of Observation and the Theory-Ladenness of the Rest of the Scientific Process", Philosophy of Science 68, S176-S186.

Briggs, C. L.: 1979, Learning How to Ask: A Sociolingual Appraisal of the Role of the Interview in Social Science Research. Cambridge University Press, Cambridge, UK.

Churchland, P. M.: 1979, Scientific Realism and the Plasticity of Mind, Cambridge University Press, Cambridge, UK.

Clough, M. P.: 1994, "Diminish Students' Resistance to Biological Evolution", The American Biology Teacher 56, 409-415.

Conn, S.: 1998, Museums and American Intellectual Life, 1876-1926, University of Chicago Press, Chicago, IL.

Creation Research Society: 2008, "Worldwide Directory of Creationist Organizations". From http://www.creationresearch.org/organizations/organizations.htm.

Crew, S. R., \& Sims, J. E.: 1991, "Locating Authenticity: Fragments of a Dialogue". In I. Karp \& S. D. Lavine (eds) Exhibiting Cultures: The Poetics and Politics of Museum Display, Smithsonian Institution Press, Washington, DC, 159-175.

Da-Silva, C., Mellado, V., Ruiz, C., \& Porlán, R.: 2007, "Evolution of the Conceptions of a Secondary Education Biology Teacher: Longitudinal Analysis Using Cognitive Maps", Science Education 91, 461-491.

Darwin, C.: 1859/2009, On the Origin of Species by Means of Natural Selection, or the Preservation of Favoured Races in the Struggle for Life, J. Endersby (ed.), Cambridge University Press, Cambridge, UK. 
Dean, D.: 1994, Museum Exhibition: Theory and Practice, Routledge, London.

Dingus, L., Tedford, R., Gaffney, E., McKenna, M., Novacek, M., \& Delson, E.: 1994, Mammals and Their Extinct Relatives: A Guide to the Lila Acheson Wallace Wing, American Museum of Natural History, New York.

Dumit, J.: 2004, Picturing Personhood: Brain Scans and Biomedical Identity. Princeton University Press, Princeton, NJ.

Farber, P.: 2003, "Teaching Evolution and the Nature of Science", The American Biology Teacher 65, 347-354.

Feyerabend, P. K.: 1975, Against Method: Outline of an Anarchistic Theory of Knowledge, NLB, London.

Flammer, L.: 2006, "The Importance of Teaching the Nature of Science", The American Biology Teacher 68, 197-198.

Flyvbjerg, B.: 2004, "Five Misunderstandings About Case-Study Research". In C. Seale, G. Gobb, J. F. Gubrium, \& D. Silverman, Qualitative Research Practice, Sage Publications, Thousand Oaks, CA 420-434.

Flyvbjerg, B.: 2001, Making Social Science Matter: Why Social Inquiry Fails and How It Can Succeed Again, S. Sampson (trans.), Cambridge University Press, Cambridge, UK.

Fodor, J.: 1984, "Observation Reconsidered", Philosophy of Science 51, 23-43. Fontana, A., \& Frey, J. H.: 2003, "The Interview: From Structured Questions to Negotiated Text". In N. K. Denzin \& Y. S. Lincoln (eds) Collecting and Interpreting Qualitative Materials, Sage Publications, Thousand Oaks, CA, 61106.

Gurian, E. H.: 1991, "Noodling around with Exhibition Opportunities." In I. Karp \& S. D. Lavine (eds) Exhibiting Cultures: The Poetics and Politics of Museum Display, Smithsonian Institution Press, Washington, DC, pp. 176-190.

Ham, K.: 2008, "Dinosaurs and the Bible", Answers in Genesis. From http://www.answersingenesis.org/docs/2.asp.

Hanson, N. R.: 1969, Perception and Discovery: An Introduction to Scientific Inquiry, Freeman, Cooper, \& Company, San Francisco, CA.

Hanson, N. R.: 1958, Patterns of Discovery: An Inquiry into the Conceptual Foundations of Science, Cambridge University Press, Cambridge, UK.

Harrison, P.: 2006, "The Bible and the Emergence of Modern Science", Science and Christian Belief 18, 115-132.

Hipkins, R.: 2005, "Teaching the 'Nature of Science': Modest Adaptations or Radical Reconceptions?", International Journal of Science Education 27, 243-254.

Hjorth, J., Flink, M., Göransson, B. \& Olsson, I.: 1977, "How to Make a Rotten Exhibition", Curator 20, 185-204.

Hodder, I.: 2003, "The Interpretation of Documents and Material Culture". In N. K. Denzin \& Y. S. Lincoln (eds) Collecting and Interpreting Qualitative Materials, Sage, Thousand Oaks, CA, pp. 155-175.

Jacoby, B. A., \& Spargo, P. E.: 1989, "Ptolemy Revisited?: The Existence of a Mild Instrumentalism in Some Selected British, American, and South African High School Physical Science Textbooks", Interchange 20, 33-53.

Johnson, R. L., \& Peeples, E. E.: 1987, "The Role of Scientific Understanding in College Student Acceptance of Evolution", The American Biology Teacher 49, 93-98. 
Kuhn, T. S.: 1970, The Structure of Scientific Revolutions, University of Chicago Press, Chicago.

Lakatos, I.: 1972, "Falsification and the Methodology of Scientific Research Programmes". In I. Lakatos \& A. Musgrave (eds) Criticism and the Growth of Knowledge, Cambridge University Press, Cambridge, UK, pp. 91-196.

Maisey, J. G., Gaffney, E. S., Norell, M. A., Posen, M., \& Dingus, L.: 1996, The Hall of Vertebrate Origins: A Guide to Fishes, Amphibians, Turtles, Lizards, Crocodiles, and Pterosaurs, American Museum of Natural History, New York.

Marsden, G. M.: 1991, Understanding Fundamentalism and Evangelicalism, Wm. B. Eerdmans Publishing Co., Grand Rapids, MI.

Marsden, G. M.: 1984, "Understanding Fundamentalist Views of Science". In A. Montagu (ed.), Science and Creationism, Oxford University Press, New York, pp. 95-116.

Marsden, G. M.: 1980, Fundamentalism and American Culture: The Shaping of Twentieth-Century Evangelicalism, 1870-1925, Oxford University Press, New York.

Matthews, M. R.: 1994, Science Teaching: The Role of History and Philosophy of Science, Routledge, New York.

McComas, W. F., Clough, M. P., \& Almazroa, H.: 1998, "The Role and Character of the Nature of Science in Science Education". In W. F. McComas (ed.) The Nature of Science in Science Education: Rationales and Strategies, Kluwer Academic Publishers, Dordrecht, The Netherlands, pp. 3-39.

Miles, R. S., Alt, M. B., Gosling, D. C., Lewis, B. N., \& Tout, A. F.: 1988, The Design of Educational Exhibits (2nd ed.), Unwin Hyman, London.

Morris, J. D.: 1980, Tracking Those Incredible Dinosaurs . . And the People Who Knew Them, Creation-Life Publishers, San Diego, CA.

Mortenson, T.: 2010, "The 19th Century Scriptural Geologists: Historical Background", Answers in Genesis. From http://www.answersingenesis.org/Home/Area/bios/scriptural_geologists.asp.

Myers, N. R.: 2007, "American Pestalozzianism Revisited: Alfred Holbrook and the Origins of Object-Based Pedagogy in 19th Century America", American Educational History Journal 34, 85-96.

Narguizian, P.: 2004, "Understanding the Nature of Science through Evolution", The Science Teacher 71, 40-45.

National Academy of Sciences: 1998, Teaching About Evolution and the Nature of Science, National Academy Press, Washington, DC.

National Association of Biology Teachers: 2001, "Statement on Teaching Evolution". In B. J. Alters \& S. M. Alters (eds) Defending Evolution in the Classroom: A Guide to the Creation/Evolution Controversy, Jones \& Bartlett, Sudbury, MA, 213-218.

National Science Teachers Association: "NSTA Position Statement: The Teaching of Evolution". From http://www.nsta.org/main/pdfs/PositionStatement_Evolution.pdf.

Nickels, M. K., Nelson, C. E., \& Beard, J.: 1996, "Better Biology Teaching by Emphasizing Evolution and the Nature of Science", The American Biology Teacher 58, 332-336. 
Oard, M. J.: 2002, "Dealing Carefully with the Data", Creation Ex Nihilo Technical Journal 16, 82-85.

Oard, M. J.: 2000, "Doppler Toppler", Creation Ex Nihilo Technical Journal 14, 39-45.

Olson, S.: 2004, Evolution in Hawaii: A Supplement to Teaching About Evolution and the Nature of Science, National Academies Press, Washington, DC.

Patton, D. R.: 2000, Creation Evidence from South America [DVD], Self-Published.

Pennock, R. T.: 1999, Tower of Babel: The Evidence against the New Creationism, MIT Press, Cambridge, MA.

Rutledge, M. L., \& Warden, M. A.: 2000, "Evolutionary Theory, the Nature of Science \& High School Biology Teachers: Critical Relationships", The American Biology Teacher 62, 23-31.

Rutledge, M. L., \& Warden, M. A.: 1999, "The Development and Validation of the Measure of Acceptance of the Theory of Evolution Instrument", School Science and Mathematics 99, 13-18.

Scharmann, L. C.: 1990, "Enhancing an Understanding of the Premises of Evolutionary Theory: The Influence of a Diversified Instructional Strategy", School Science and Mathematics 90, 91-100.

Scharmann, L. C., \& Harris, W. M.: 1992, "Teaching Evolution: Understanding and Applying the Nature of Science", Journal of Research in Science Teaching 29, 375-388.

Scharmann, L. C., Smith, M. U., James, M. C., \& Jensen, M.: 2005, "Explicit Reflective Nature of Science Instruction: Evolution, Intelligent Design, and Umbrellaology", Journal of Science Teacher Education 16, 27-41.

Silverman, D.: 2003, "Analyzing Talk and Text". In N. K. Denzin \& Y. S. Lincoln (eds) Collecting and Interpreting Qualitative Materials, Sage, Thousand Oaks, CA, pp. 340-362.

Smith, M. U.: 2010, "Current Status of Research in Teaching and Learning Evolution: I. Philosophical/Epistemological Issues", Science \& Education 19, 523-538.

Spencer, H. A. D.: 2002, "Exhibition Text Guidelines". In B. Lord \& G. D. Lord (eds) The Manual of Museum Exhibitions, AltaMira Press, Walnut Creek, CA, pp. 398400.

Stake, R. E.: 2003, "Case Studies". In N. K. Denzin \& Y. S. Lincoln (eds) Strategies of Qualitative Inquiry, Sage, Thousand Oaks, CA, 134-164.

Swift, D.: 2006, Secrets of the Ica Stones and Nazca Lines, Self-Published.

Taylor, C. A., 1996: Defining Science: A Rhetoric of Demarcation, University of Wisconsin Press, Madison, WI.

Taylor, C. A., 1992: "Of Audience, Expertise and Authority: The Evolving Creationism Debate", Quarterly Journal of Speech 78, 277-295.

Vogel, S.: 1991, "Always True to the Object, in Our Fashion". In I. Karp \& S. D. Lavine (eds) Exhibiting Cultures: The Poetics and Politics of Museum Display, Smithsonian Institution Press, Washington, DC, pp. 191-204.

Weil, Stephen E.: 1990a, "The Proper Business of the Museum: Ideas or Things?". In Rethinking the Museum, Smithsonian Institution Press, Washington, DC, pp. 4356.

Weil, Stephen E.: 1990b, "Legal Aspects of the Display of Imitations". In Rethinking the Museum, Smithsonian Institution Press, Washington, DC, pp. 161-166. 
Weinstein, M.: 1998, Robot World: Education, Popular Culture, and Science, Peter Lang, New York.

Whitcomb, J. C., \& Morris, H. M.: 1961, The Genesis Flood: The Biblical Record and Its Scientific Implications, Presbyterian and Reformed Publishing Company, Phillipsburg, NJ.

Wyse Jackson, P. N.: 2006, The Chronologers' Quest: Episodes in the Search for the Age of the Earth, Cambridge University Press, Cambridge, UK. 